\section{Coconut Coir and Peat Biocontainers Influence Plant Growth Retardant Drench Efficacy}

\author{
Nicholas J. Flax ${ }^{1}$, Christopher J. Currey ${ }^{1,3,4}$, James A. Schrader ${ }^{1}$, \\ David Grewell ${ }^{2}$, and William R. Graves ${ }^{1}$
}

ADDITIONAL INDEX WORDs. angelonia, bioplastic, petunia, plant growth regulator, PGR, substrate drench

Summary. We evaluated the effects of seven types of 4.5-inch top-diameter biocontainers and five rates of paclobutrazol drench on the growth and development of angelonia (Angelonia angustifolia 'Serena White') and petunia (Petunia $\times$ bybrida 'Wave ${ }^{\circledR}$ Purple Improved Prostrate') during greenhouse production. The container types included were biopolyurethane-coated paper fiber; uncoated paper fiber; rice hull; coconut coir; peat; two types of bioplastic container, one made from $90 \%$ polylactic acid (PLA) and 10\% lignin [PLA-lignin (90/10 by weight)] and another made from $60 \%$ PLA and $40 \%$ soy polymer with adipic anhydride [SP.A [PLA-SP. A]; (60/40 by weight $)\}$; and a petroleum-based plastic control. All containers were filled with $590 \mathrm{~mL}$ of substrate composed of (by vol) $75 \%$ canadian sphagnum moss and $25 \%$ perlite. Ten days after transplanting seedlings, 2 -fl oz aliquots of deionized water containing $0,1,2.5,5,10$, or $20 \mathrm{mg} \cdot \mathrm{L}^{-1}$ paclobutrazol were applied to the substrate surface as drenches. The date of anthesis was recorded for each plant, and growth data were collected 6 weeks after transplant. Shoots were harvested and dried and shoot dry weight (SDW) was recorded. Height (angelonia only) and diameter of angelonia and petunia and time to flower were calculated. Container type and paclobutrazol concentration interacted to affect size and SDW of angelonia and petunia. Growth index of angelonia treated with $0 \mathrm{mg} \cdot \mathrm{L}^{-1}$ paclobutrazol and grown in coir and peat containers was $19 \%$ to $29 \%$ and $29 \%$ to $38 \%$ smaller than that of plants in other container types, respectively. Diameter of untreated petunia grown in peat containers was similar to that of those grown in coir and uncoated paper fiber containers, but was smaller $(10.9$ to $13.5 \mathrm{~cm})$ than that of plants grown in other container types. As paclobutrazol concentrations increased from 0 to $20 \mathrm{mg} \cdot \mathrm{L}^{-1}$ treatments, SDWs of petunia grown in coir containers were suppressed by $23 \%$, whereas plants grown in rice hull containers were up to $45 \%$ less. Our results indicate that growth suppression of angelonia and petunia grown in biocontainers using paclobutrazol drenches varies by the type of biocontainer. Producers should reduce paclobutrazol drench concentrations to produce plants of appropriate size if substituting coir or peat biocontainers for traditional petroleum plastics, whereas no adjustment in plant growth retardant (PGR) drench concentrations is required for plants produced in the other biocontainer types we evaluated.

$\mathrm{T}$ The wholesale value of floriculture crops in the United States exceeded $\$ 5.87$ billion in 2014 (U.S. Department of Agriculture, 2015), of which $\approx 44 \%(\$ 2.56$ billion) was attributed to annual

We gratefully acknowledge Peter Lawlor for greenhouse assistance; Kellie Walters, Alexander Litvin, Brianna Vest, and Erica Schlichte for assistance with establishment of experiments and data collection; and Fine Americas, Inc. and Wagner Greenhouses for plant growth regulator and plant material, respectively. Funding was provided by the U.S. Department of Agriculture, Specialty Crops Research Initiative, and National Institute of Food and Agriculture.

${ }^{1}$ Department of Horticulture, Iowa State University, 106 Horticulture Hall, Ames, IA 50011

${ }^{2}$ Department of Agricultural and Biosystems Engineering, Iowa State University, 4356 Elings Hall, Ames, IA 50011

${ }^{3}$ Assistant professor

${ }^{4}$ Corresponding author. E-mail: ccurrey@iastate.edu. https://doi.org/10.21273/HORTTECH04033-18 bedding and garden plants. Unlike food-crop producers, for whom fruit or plant biomass production is the primary objective, the goal of beddingplant producers is to grow plants that have high-quality aesthetics. Commercial bedding-plant producers often grow a diverse range of species in common environments which present challenges, as plants respond differently to environmental conditions and cultural factors (Andersson, 2011; Blanchard and Runkle, 2011).
To produce plants of acceptable size and quality, bedding-plant producers manipulate environmental parameters such as light and temperature (Erwin et al., 1989; Faust et al., 2005) or use crop culture practices such as withholding water (Alem et al., 2016) or changing mineral nutrient source, concentration, or delivery system (Klock-Moore and Broschat, 2001) to control growth. However, providing species-specific cultural practices can be challenging in production environments containing many species and may not be practical or feasible depending on the facility and available equipment. Plant growth retardants are frequently used in bedding-plant production to restrict growth of plants, as they can be easily applied without adversely affecting other crops in the same environment.

Plant growth retardants are often applied as foliar sprays, but research has shown that longer term growth restriction and more uniform control can be achieved when they are applied as substrate drenches (Boldt, 2008; Gent and McAvoy, 2000; Whipker et al., 2006). As a result, PGR drench applications are a preferred method among many producers (Owen et al., 2016). Efficacy of PGR applications can be affected by plant genetics (Currey et al., 2016b), active ingredient (Currey et al., 2016a), application method (Hawkins et al., 2015), and, in the case of substrate drenches, substrate components (Barrett, 1982; Bonaminio and Larson, 1978; Currey et al., 2010). Substrate components such as pine (Pinus sp.) bark can reduce the efficacy of PGR drenches (Bonaminio and Larson, 1978), whereas the presence of parboiled rice (Oryza sativa) hulls in substrate does not (Currey et al., 2010).

Biocontainers, which provide an alternative to petroleum plastic plant containers, can be manufactured from a variety of organic parent materials and vary in both physical and chemical properties (Conneway et al., 2015; Evans et al., 2010;

\begin{tabular}{llll}
\hline $\begin{array}{l}\text { Units } \\
\text { To convert U.S. to SI, } \\
\text { multiply by }\end{array}$ & U.S. unit & SI unit & $\begin{array}{l}\text { To convert SI to U.S., } \\
\text { multiply by }\end{array}$ \\
\hline 29.5735 & $\mathrm{fl} \mathrm{oz}$ & $\mathrm{mL}$ & 0.0338 \\
2.54 & inch $(\mathrm{es})$ & $\mathrm{cm}$ & 0.3937 \\
28.3495 & $\mathrm{Oz}$ & $\mathrm{g}$ & 0.0353 \\
1 & $\mathrm{ppm}$ & $\mathrm{mg} \cdot \mathrm{L}^{-1}$ & 1 \\
$\left({ }^{\circ} \mathrm{F}-32\right) \div 1.8$ & ${ }^{\circ} \mathrm{F}$ & ${ }^{\circ} \mathrm{C}$ & $\left({ }^{\circ} \mathrm{C} \times 1.8\right)+32$
\end{tabular}


Grewell et al., 2014). With new biocontainers entering the commercial market, including some bioplastic containers that release supplemental nutrients as they degrade (Currey et al., 2014, 2015; Schrader et al., 2013) and other biocontainer types whose physical properties influence plant growth by reducing available water to plants (Evans and Hensley, 2004; Evans et al., 2010), we hypothesized that some biocontainer types may influence PGR drench efficacy. We have found no previous research that investigates this potential interaction. Therefore, our objectives were to determine the effects of different types of biocontainers on the efficacy of paclobutrazol substrate drench when using a variety of commercially available biocontainers and two novel bioplastic-based containers

\section{Materials and methods}

Container types. Eight types of 4.5-inch top-diameter containers were used, including fiber-based, biocomposite, bioplastic, and injectionmolded petroleum plastic containers (Table 1). Biocontainer types were selected to represent the diverse range of commercially available and developing classes of biocontainers.

Paclobutrazol treatments AND CUlTure. Containers were filled with $590 \mathrm{~mL}$ of commercial substrate composed of (by vol) 75\% canadian sphagnum (Spagnum sp.) moss, 25\% perlite, dolomitic limestone, and wetting agent (Sunshine Mix \#l; Sun Gro Horticulture, Agawam, MA). The same amount of substrate was used for each container type to account for different container volumes. Seedlings of angelonia and petunia grown in a 288-cell plug tray and received from a commercial producer (Wagner Greenhouses, Minneapolis, MN) were transplanted individually into containers on 9 Sept. and 11 Nov. 2015, respectively. Paclobutrazol drenches were applied to the substrate surface $10 \mathrm{~d}$ after transplant. Treatments consisted of 2 -fl oz aliquots of deionized water containing 0,1 , $2.5,5,10$, or $20 \mathrm{mg} \cdot \mathrm{L}^{-1}$ paclobutrazol (Piccolo; Fine Americas, Walnut Grove, CA).

Plants were grown for 6 weeks in a glass-glazed greenhouse with retractable shade curtains, fog cooling, radiant hot-water heating, and 1000W high-pressure sodium lamps that operated between 0600 and $2200 \mathrm{HR}$ to provide a supplemental photosynthetic photon flux (PPF) of $164 \pm$ $20 \mu \mathrm{mol} \cdot \mathrm{m}^{-2} \cdot \mathrm{s}^{-1}$ at plant height [measured by a quantum sensor (LI-190 SB; LI-COR Biosciences, Lincoln, $\mathrm{NE})]$ and to maintain a target daily light integral of about $13 \mathrm{~mol} \cdot \mathrm{m}^{-2} \cdot \mathrm{d}^{-1}$. Average daily air temperature was recorded by thermocouples (41342; R.M. Young Co., Traverse City, MI) housed within actively aspirated radiation shields (43502; R.M. Young Co.). Quantum sensors and thermocouples were connected to a data logger

Table 1. 'Serena White' angelonia and 'Wave ${ }^{\circledR}$ Purple Improved Prostrate' petunia were grown in seven different types of 4.5 -inch $(11.43 \mathrm{~cm})$ top-diameter biocontainers and petroleum plastic (control) container filled with substrate that comprised (by vol) $75 \%$ canadian sphagnum moss and $25 \%$ perlite, and treated with 2 -fl oz $(59.1 \mathrm{~mL})$ aliquots of deionized water containing $0,1,2.5,5,10$, or $20 \mathrm{mg} \cdot \mathrm{L}^{-1}(\mathrm{ppm})$ paclobutrazol. Biocontainers included novel biopolymer containers made from PLA and lignin powder, PLA and SP.A, paper fiber twice dip-coated in a castor oil-based biopolyurethane, uncoated paper fiber, rice hull, coconut coir, and peat. ${ }^{\mathrm{z}}$

\begin{tabular}{|c|c|c|}
\hline Container type ${ }^{\mathrm{z}}$ & $\operatorname{Vol}(\mathrm{mL})^{\mathrm{y}}$ & Manufacturer \\
\hline PLA-lignin $(90 / 10)$ & 698 & Vistatek $^{\circledR}$, Stillwater, MN \\
\hline PLA-SP.A $(60 / 40)$ & 698 & Vistatek $^{\circledR}$ \\
\hline Biopolyurethane-coated paper & 600 & Myers Industries, Middlefield, $\mathrm{OH}$ \\
\hline Uncoated paper & 600 & Myers Industries \\
\hline Rice hull & 590 & Summit Plastics, Tallmadge, $\mathrm{OH}$ \\
\hline Coconut coir & 610 & Myers Industries \\
\hline Peat & 760 & $\begin{array}{l}\text { Jiffy Products of America, } \\
\text { Lorain, } \mathrm{OH}\end{array}$ \\
\hline Petroleum plastic & 655 & Myers Industries \\
\hline
\end{tabular}

${ }_{\mathrm{z}}$ Numbers in parentheses denote (by weight) respective percentages of parent materials. Biopolyurethance coating was applied at Iowa State University, Ames.

${ }^{\mathrm{y}} \mathrm{l} \mathrm{mL}=0.0338 \mathrm{fl} \mathrm{oz}$

PLA = polylactic acid (a commercial biopolymer $) ; \mathrm{SP} . \mathrm{A}=$ soy polymer with adipic anhydride

(CRl000 Measurement and Control System; Campbell Scientific, Logan, UT) that measured air temperature and $P P F$ every $15 \mathrm{~s}$ and logged averages every 15 min (Table 2). Greenhouse environment set points were maintained by an environment control computer (Titan; ARGUS Control Systems, Surrey, Canada).

Plants were fertilized once per week with a blended water-soluble fertilizer [50 and $100 \mathrm{mg} \cdot \mathrm{L}^{-1}$ nitrogen provided from $21 \mathrm{~N}-2.2 \mathrm{P}-16.6 \mathrm{~K}$ and $15 \mathrm{~N}-2.2 \mathrm{P}-12.5 \mathrm{~K}$, respectively (Everris NA Inc., Marysville, $\mathrm{OH}$ )] to provide (in milligrams per liter) 150 nitrogen, 8.6 phosphorous, 92.2 potassium, 33.3 calcium, $13.3 \mathrm{mag}$ nesium, 0.75 iron, 0.4 manganese, 0.4 zinc, 0.2 copper, 0.2 boron, and 0.5 molybdenum. Between fertilizer applications, plants were irrigated by hand with tempered municipal water with minimal leaching to maintain similar amounts of fertilizer provided to plants across treatments. Clear water irrigations occurred when the substrate surface was visibly dry (Evans and Hensley, 2004). Plants were irrigated only once per day when needed, but were not allowed to reach the point of incipient wilting. All plants within a given container type and paclobutrazol concentration combination were watered simultaneously when one container's substrate surface was dry, and the number of irrigations, including fertilizer applications, was recorded. Based on results from a preliminary experiment (data not presented), plants were grouped by container type to ensure that container and paclobutrazol combinations were irrigated uniformly within each container type.

DATA COLLECTION AND CAlCulation. Plant growth data were collected 6 weeks after transplant. Height from the substrate surface to the tallest growing point including the inflorescence (angelonia only), widest diameter (diameter 1 ), and width $90^{\circ}$ from the widest diameter (diameter 2 ) of each plant were recorded, and mean shoot diameter [(diameter $1+$ diameter 2)/2] was calculated; height of petunia was not measured because of its prostrate growth habit. Shoots were severed at the substrate surface, dried in a forced-air oven at $67^{\circ} \mathrm{C}$ for $3 \mathrm{~d}$, weighed, and SDW was recorded. Date of anthesis was recorded for 
Table 2. Daily light integral (DLI), average daily temperature (ADT), and average day (DT) and night (NT) temperatures for 'Serena White' angelonia and 'Wave ${ }^{\circledR}$ Purple Improved Prostrate' petunia grown in seven types of 4.5-inch (11.43 $\left.\mathrm{cm}\right)$ topdiameter biocontainers and a petroleum plastic (control) container filled with substrate that comprised (by vol) $75 \%$ canadian sphagnum moss and $25 \%$ perlite, and treated with $2-\mathrm{fl} \mathrm{oz}(59.1 \mathrm{~mL})$ aliquots of deionized water containing $0,1,2.5,5,10$, or $20 \mathrm{mg} \cdot \mathrm{L}^{-1}(\mathrm{ppm})$ paclobutrazol.

\begin{tabular}{lccrr}
\hline & \multicolumn{3}{c}{ Environmental data $($ mean \pm SD $)$} \\
\cline { 2 - 5 } Species & DLI $\left(\mathbf{m o l} \cdot \mathbf{m}^{-2} \cdot \mathbf{d}^{-\mathbf{1}}\right)$ & ADT $\left({ }^{\circ} \mathbf{C}\right)^{\mathbf{z}}$ & DT $\left({ }^{\circ} \mathbf{C}\right)$ & NT $\left({ }^{\circ} \mathbf{C}\right)$ \\
\hline Angelonia & $12.7 \pm 1.9$ & $22.3 \pm 1.1$ & $23.1 \pm 1.1$ & $20.8 \pm 1.2$ \\
Petunia & $13.5 \pm 1.8$ & $20.3 \pm 0.7$ & $20.7 \pm 0.7$ & $19.0 \pm 0.4$ \\
\hline
\end{tabular}

${ }^{\mathrm{z}}\left(1.8 \times{ }^{\circ} \mathrm{C}\right)+32={ }^{\circ} \mathrm{F}$.

each plant, and time to flower was calculated.

EXPERIMENTAL DESIGN AND STATISTICAL ANALYSES. This experiment was conducted using a randomized complete block design in factorial arrangement with container type (eight containers) and paclobutrazol concentration (six concentrations) as factors; each factorial was replicated seven times $(n=7)$. Analyses of variance were performed using PROC GLM of SAS (version 9.4; SAS Institute, Cary, NC), and mean separations across container types were performed using Tukey's honestly significant difference test at $P \leq 0.05$ and linear and quadratic regression analyses were performed using SigmaPlot (version 12.5; Systat Software, San Jose, CA). For analyses where the interaction between container type and paclobutrazol concentration was significant, mean separation was performed across container types within each paclobutrazol concentration, whereas regression analyses were performed across paclobutrazol concentrations within each container type. Alternatively, where the interaction between container type and paclobutrazol concentration was not significant, the main effects were analyzed. To analyze the main effect of container type, data were pooled across paclobutrazol concentrations within container type for each species and mean separation was performed across container types. To analyze the effect of paclobutrazol concentration, data were pooled across container types within paclobutrazol concentration for each species and regression analyses were performed.

\section{Results}

Angelonia. Time to flower was affected by container type and paclobutrazol concentration, but no interactions were observed (Table 3 ). Plants in PLA-lignin containers flowered about $3 \mathrm{~d}$ earlier than peat

Table 3. Analyses of variance of container type (C) and paclobutrazol concentration (P) on time to flower, height (angelonia only), diameter, and shoot dry weight (SDW) of 'Serena White' angelonia and 'Wave ${ }^{\circledR}$ Purple Improved Prostrate' petunia grown in seven types of 4.5 -inch $(11.43 \mathrm{~cm})$ topdiameter biocontainers and a petroleum plastic (control) container filled with substrate that comprised (by vol) $75 \%$ canadian sphagnum moss and $25 \%$ perlite, and treated with $2-\mathrm{fl} \mathrm{oz}(59.1 \mathrm{~mL})$ aliquots of deionized water containing 0,1 , $2.5,5,10$, or $20 \mathrm{mg} \cdot \mathrm{L}^{-1}(\mathrm{ppm})$ paclobutrazol.

\begin{tabular}{lccc}
\hline Parameter & $\mathbf{C}$ & $\mathbf{P}$ & $\mathbf{C} \times \mathbf{P}$ \\
\hline Time to flower & $* * *$ & Angelonia & NS \\
Height & $* * *$ & $* * *$ & NS \\
Diameter & $* * *$ & $* * *$ & $* * *$ \\
SDW & $* * *$ & $* * *$ & $* * *$ \\
Time to flower & $* * *$ & Petunia & NS \\
Diameter & $* * *$ & $* * *$ & $* *$ \\
SDW & $* * *$ & $* * *$ & $* * *$ \\
Ns, ${ }^{*}, * *$ Nonsignificant or significant at $P \leq 0.01$ or 0.001 , respectively. & &
\end{tabular}

containers (Table 4). Alternatively, plants treated with $0 \mathrm{mg} \cdot \mathrm{L}^{-1}$ paclobutrazol flowered $\approx 4 \mathrm{~d}$ earlier than those treated with $20 \mathrm{mg} \cdot \mathrm{L}^{-1}$ (Table 5 ).

Both container type and paclobutrazol concentration affected plant height but did not interact (Table 3 ). All container types except for peat containers yielded plants of similar height, whereas plants grown in peat containers were $11 \%$ to $17 \%$ shorter than those grown in other container types (Table 4). Plant height decreased curvilinearly as paclobutrazol concentrations increased from 0 to $20 \mathrm{mg} \cdot \mathrm{L}^{-1}$ (Table 5 ).

Container type and paclobutrazol concentration interacted to affect plant diameter (Table 3). For example, at $0 \mathrm{mg} \cdot \mathrm{L}^{-1}$ paclobutrazol, diameter of plants grown in all container types except for coconut coir (Cocos nucifera) and peat containers was similar to that of those grown in petroleum plastic containers, whereas plants in coir and peat containers were $43 \%$ and $56 \%$ smaller, respectively (Table 6). Alternatively, at $10 \mathrm{mg} \cdot \mathrm{L}^{-1}$ paclobutrazol, only the diameter of plants grown in peat containers was smaller than that of those grown in petroleum plastic containers (Table $6)$. Within container type and across paclobutrazol concentrations, diameter of plants produced in coir containers and treated with $5 \mathrm{mg} \cdot \mathrm{L}^{-1}$ paclobutrazol was $26 \%$ smaller than that of the $0 \mathrm{mg} \cdot \mathrm{L}^{-1}$ control plants, whereas angelonia in PLA-SP.A containers treated with $5 \mathrm{mg} \cdot \mathrm{L}^{-1}$ paclobutrazol $(17.5 \mathrm{~cm})$ were $43 \%$ smaller than their corresponding control (Table 6). As paclobutrazol concentration increased, plant diameter was curvilinearly suppressed in all container types.

Container type and paclobutrazol concentration also interacted to affect SDW (Table 3). Shoot dry weight of plants treated with $0 \mathrm{mg} \cdot \mathrm{L}^{-1}$ paclobutrazol and grown in PLA-lignin containers was greatest $(5.4 \mathrm{~g})$ and was similar to that of plants in PLASP.A, rice hull, and petroleum plastic containers (Table 6). Plants in biopolyurethane-coated paper fiber (4.4 g) and uncoated paper fiber (4.3 g) containers were $19 \%$ to $20 \%$ smaller 
Table 4. Container type affected height of (angelonia only) and time to flower of 'Serena White' angelonia and 'Wave ${ }^{\circledR}$ Purple Improved Prostrate' petunia grown in seven types of 4.5 -inch $(11.43 \mathrm{~cm})$ top-diameter biocontainers and a petroleum plastic (control) container filled with substrate that comprised (by vol) $75 \%$ canadian sphagnum moss and $25 \%$ perlite, and was treated with 2 -fl oz $(59.1 \mathrm{~mL})$ aliquots of deionized water containing $0,1,2.5,5,10$, or $20 \mathrm{mg} \cdot \mathrm{L}^{-1}(\mathrm{ppm})$ paclobutrazol. Angelonia height data were collected 6 weeks after transplant. Date of anthesis was recorded for each plant and time to flower from transplant was calculated. Data were pooled across paclobutrazol concentrations within container type for each species and mean separation was performed across container types.

\begin{tabular}{lccc}
\hline & $\begin{array}{c}\text { Angelonia } \\
\text { ht }(\mathbf{c m})^{\mathbf{y}}\end{array}$ & \multicolumn{2}{c}{ Time to flower $(\mathbf{d})$} \\
\cline { 3 - 4 } Container type $^{\mathrm{z}}$ & $22.3 \mathrm{a}^{\mathrm{x}}$ & $34.8 \mathrm{c}$ & $35.0 \mathrm{bc}$ \\
\hline PLA-lignin $(90 / 10)$ & $22.2 \mathrm{a}$ & $35.9 \mathrm{~b}$ & $33.9 \mathrm{c}$ \\
PLA-SP.A $(60 / 40)$ & $22.2 \mathrm{a}$ & $36.0 \mathrm{~b}$ & $34.0 \mathrm{c}$ \\
Biopolyurethane-coated paper & $22.0 \mathrm{a}$ & $35.6 \mathrm{bc}$ & $34.0 \mathrm{c}$ \\
Uncoated paper & $21.9 \mathrm{a}$ & $35.1 \mathrm{bc}$ & $32.9 \mathrm{~d}$ \\
Rice hull & $21.0 \mathrm{a}$ & $35.8 \mathrm{bc}$ & $38.0 \mathrm{a}$ \\
Coconut coir & $18.7 \mathrm{~b}$ & $37.7 \mathrm{a}$ & $38.7 \mathrm{a}$ \\
Peat & $21.7 \mathrm{a}$ & $35.0 \mathrm{bc}$ & $36.0 \mathrm{~b}$ \\
Petroleum plastic &
\end{tabular}

${ }^{\mathrm{z}}$ Numbers in parentheses denote (by weight) respective percentages of parent materials. Biopolyurethance coating was applied at Iowa State University, Ames.

${ }^{\mathrm{y}} 1 \mathrm{~cm}=0.3937$ inch.

${ }^{\mathrm{x}}$ Means within columns that share letters do not differ based on Tukey's honest significant difference test at $P \leq 0.05$.

PLA = polylactic acid; SP.A = soy polymer with adipic anhydride.

Table 5. Paclobutrazol concentration affected height (angelonia only) and time to flower of 'Serena White' angelonia and 'Wave ${ }^{\circledR}$ Purple Improved Prostrate' petunia grown in seven types of 4.5 -inch $(11.43 \mathrm{~cm})$ top-diameter biocontainers and a petroleum plastic (control) container filled with substrate that comprised (by vol) $75 \%$ canadian sphagnum moss and $25 \%$ perlite, and was treated with 2 -fl oz $(59 \mathrm{~mL})$ aliquots of deionized water containing $0,1,2.5,5,10$, or $20 \mathrm{mg} \cdot \mathrm{L}^{-1}$ paclobutrazol. Angelonia height data were collected 6 weeks after transplant. Date of anthesis was recorded for each plant and time to flower from transplant was calculated. Data were pooled across container types within paclobutrazol concentration for each species and linear $(\mathrm{L})$ and quadratic $(\mathrm{Q})$ regression analyses were performed across paclobutrazol concentration.

\begin{tabular}{|c|c|c|c|}
\hline \multirow{2}{*}{$\begin{array}{l}\text { Paclobutrazol concn } \\
\left(\mathrm{mg} \cdot \mathrm{L}^{-1}\right)^{\mathrm{z}}\end{array}$} & \multirow{2}{*}{$\begin{array}{c}\text { Angelonia } \\
\text { ht }(\mathrm{cm})^{\mathrm{z}}\end{array}$} & \multicolumn{2}{|c|}{ Time to flower (d) } \\
\hline & & Angelonia & Petunia \\
\hline 0 & 31.4 & 34.2 & 34.3 \\
\hline 1 & 28.8 & 34.4 & 34.7 \\
\hline 2.5 & 24.1 & 34.9 & 35.0 \\
\hline 5 & 18.3 & 36.0 & 35.2 \\
\hline 10 & 14.7 & 36.7 & 36.1 \\
\hline 20 & 11.7 & 38.3 & 36.5 \\
\hline Significance & $\mathrm{L}^{* * *}, \mathrm{Q}^{* * *}$ & $\mathrm{~L}^{* * *}, \mathrm{Q}^{* * *}$ & $\mathrm{~L}^{* * *}, \mathrm{Q}^{* * *}$ \\
\hline
\end{tabular}

than those in PLA-lignin, and coir and peat containers were $53 \%$ to $67 \%$ smaller, respectively (Table 6). Alternatively, at $1 \mathrm{mg} \cdot \mathrm{L}^{-1}$ paclobutrazol, plants produced in PLA-SP.A containers were largest $(5.1 \mathrm{~g})$ and were similar only to PLA-lignin and petroleum plastic ( 4.5 and $4.7 \mathrm{~g}$, respectively), whereas plants in other container types were $25 \%$ to $71 \%$ smaller than those in PLA-SP.A (Table 6). Shoot dry weight was curvilinearly suppressed as paclobutrazol concentration increased for all container types.

Petunia. Time to flower was affected by container type and paclobutrazol concentration, but no interactions were observed (Table 3 ). Plants produced in coconut (coir and peat containers flowered $2-5.1 \mathrm{~d}$ and 2.7-5.8 d later than those in other container types, respectively (Table 4 ). Plants treated with 10 and $20 \mathrm{mg} \cdot \mathrm{L}^{-1}$ paclobutrazol flowered about $2 \mathrm{~d}$ later than those treated with $0 \mathrm{mg} \cdot \mathrm{L}^{-1}$, although flowering time was similar for plants that received all other concentrations (Table 5).

Container type and paclobutrazol concentration interacted to affect diameter of petunia (Table 3 ). Plants treated with $0 \mathrm{mg} \cdot \mathrm{L}^{-1}$ paclobutrazol and grown in peat containers $(23.4 \mathrm{~cm})$ were similar to plants grown in uncoated paper fiber $(28.9 \mathrm{~cm})$ and coconut coir $(29.9 \mathrm{~cm})$ containers and were $32 \%$ to $37 \%$ smaller than those grown in other container types (Table 7). Conversely, diameter of plants in peat containers and treated with $10 \mathrm{mg} \cdot \mathrm{L}^{-1}$ paclobutrazol was similar to that of those in PLA-lignin containers, and $22 \%$ to $30 \%$ smaller than plants in other container types that received the same PGR treatment (Table 7 ). Within container type and across paclobutrazol concentrations, diameter of petunia grown in coir containers and treated with up to $10 \mathrm{mg} \cdot \mathrm{L}^{-1}$ paclobutrazol was similar $(29.9-25.6 \mathrm{~cm})$; however, within biopolyurethane-coated paper containers, only plants treated with $0-2$ $\mathrm{mg} \cdot \mathrm{L}^{-1}$ paclobutrazol were similar in diameter $(35.2-32.4 \mathrm{~cm})$ (Table 7).

Container type and paclobutrazol concentration also interacted to affect SDW (Table 3). Plants treated with $0 \mathrm{mg} \cdot \mathrm{L}^{-1}$ paclobutrazol in rice hull containers had the greatest SDW $(8.3 \mathrm{~g})$ and were similar to plants in PLA-SP.A (7.9 g) and petroleum plastic $(7.6 \mathrm{~g})$ containers; plants in all other container types were $15 \%$ to $78 \%$ smaller (Table 7). Plants treated with $5 \mathrm{mg} \cdot \mathrm{L}^{-1}$ paclobutrazol were largest among those grown in PLASP.A $(6.5 \mathrm{~g})$ containers and were similar to those grown in PLA-lignin $(5.5 \mathrm{~g})$, uncoated paper fiber $(5.8 \mathrm{~g})$, and rice hull $(6.3 \mathrm{~g})$ containers, whereas plants grown in remaining container types were $18 \%$ to $65 \%$ smaller (Table 7). Plants produced in coir containers were similar for 0-20 mg. $\mathrm{L}^{-1}$ paclobutrazol treatments, whereas plants in petroleum plastic containers that received PGR treatments were $13 \%$ to $53 \%$ smaller than those in the $0 \mathrm{mg} \cdot \mathrm{L}^{-1}$ control treatment.

\section{Discussion}

We have found no previous research investigating the effect of biocontainers on flowering of annual bedding plants. Both angelonia and petunia grown in peat containers 
Table 6. Diameter and shoot dry weight of 'Serena White' angelonia grown in seven types of 4.5-inch (11.43 cm) topdiameter biocontainers and petroleum plastic (control) filled with substrate that comprised (by vol) $75 \% \mathrm{canadian}$ sphagnum moss and $25 \%$ perlite, and treated with $2-\mathrm{fl} \mathrm{oz}(59.1 \mathrm{~mL})$ aliquots of deionized water containing $0,1,2.5,5,10$, or $20 \mathrm{mg} \cdot \mathrm{L}^{-1}$ paclobutrazol. Data were collected 6 weeks after transplant. Linear $(L)$ and quadratic $(Q)$ regression analyses were performed within container type across paclobutrazol concentration, and mean separation were performed within paclobutrazol concentration across container type.

\begin{tabular}{|c|c|c|c|c|c|c|c|}
\hline \multirow[b]{2}{*}{ Container type ${ }^{y}$} & \multicolumn{6}{|c|}{ Paclobutrazol concn $\left(\mathrm{mg} \cdot \mathrm{L}^{-1}\right)^{\mathrm{z}}$} & \multirow[b]{2}{*}{ Significance } \\
\hline & $\mathbf{0}$ & 1 & 2.5 & 5 & 10 & 20 & \\
\hline \multicolumn{8}{|c|}{ Diameter $(\mathrm{cm})^{\mathrm{z}}$} \\
\hline PLA-SP.A $(60 / 40)$ & $30.0 \mathrm{ab}$ & $29.4 \mathrm{a}$ & $24.7 \mathrm{a}$ & $16.0 \mathrm{a}$ & $13.7 \mathrm{a}$ & $12.7 \mathrm{a}$ & $\mathrm{L}^{* * *}, \mathrm{Q}^{* * *}$ \\
\hline Biopolyurethane-coated paper & $24.5 \mathrm{c}$ & $24.2 \mathrm{~b}$ & $18.9 \mathrm{~b}$ & $14.8 \mathrm{ab}$ & $11.6 \mathrm{bc}$ & $10.8 \mathrm{bc}$ & $\mathrm{L}^{* * *}, \mathrm{Q}^{* * *}$ \\
\hline Uncoated paper & $25.0 \mathrm{bc}$ & $24.6 \mathrm{~b}$ & $21.7 \mathrm{ab}$ & $15.0 \mathrm{ab}$ & $12.5 \mathrm{ab}$ & $10.9 \mathrm{bc}$ & $\mathrm{L}^{* * *}, \mathrm{Q}^{* * *}$ \\
\hline Peat & $12.4 \mathrm{~d}$ & $11.7 \mathrm{~d}$ & $10.4 \mathrm{~d}$ & $9.1 \mathrm{c}$ & $7.8 \mathrm{~d}$ & $6.4 \mathrm{~d}$ & $\mathrm{~L}^{* * *}, \mathrm{Q}^{* * *}$ \\
\hline Petroleum plastic & $27.9 \mathrm{abc}$ & $26.8 \mathrm{ab}$ & $22.2 \mathrm{ab}$ & $16.3 \mathrm{a}$ & $12.2 \mathrm{abc}$ & $11.9 \mathrm{ab}$ & $\mathrm{L}^{* * *}, \mathrm{Q}^{* \star *}$ \\
\hline \multicolumn{8}{|c|}{ Shoot dry wt $(\mathrm{g})^{\mathrm{z}}$} \\
\hline PLA-lignin $(90 / 10)$ & $5.4 \mathrm{a}$ & $4.5 \mathrm{ab}$ & $4.0 \mathrm{ab}$ & $3.1 \mathrm{ab}$ & $2.6 \mathrm{ab}$ & $2.0 \mathrm{~b}$ & $\mathrm{~L}^{* * *}, \mathrm{Q}^{* * *}$ \\
\hline PLA-SP.A $(60 / 40)$ & $4.9 \mathrm{ab}$ & $5.0 \mathrm{a}$ & $4.5 \mathrm{a}$ & $3.2 \mathrm{a}$ & $2.7 \mathrm{a}$ & $2.3 \mathrm{a}$ & $\mathrm{L}^{* * *}, \mathrm{Q}^{* * *}$ \\
\hline Peat & $1.8 \mathrm{c}$ & $1.5 \mathrm{e}$ & $1.3 \mathrm{f}$ & $1.1 \mathrm{~d}$ & $0.9 \mathrm{e}$ & $0.8 \mathrm{e}$ & $\mathrm{L}^{* * *}, \mathrm{Q}^{* * *}$ \\
\hline Petroleum plastic & $5.2 \mathrm{ab}$ & $4.7 \mathrm{a}$ & $3.9 \mathrm{abc}$ & $3.1 \mathrm{ab}$ & $2.5 \mathrm{ab}$ & $2.1 \mathrm{ab}$ & $\mathrm{L}^{* * *}, \mathrm{Q}^{* * *}$ \\
\hline
\end{tabular}

${ }^{\mathrm{z}} \mathrm{l} \mathrm{mg} \cdot \mathrm{L}^{-1}=1 \mathrm{ppm}, \mathrm{l} \mathrm{cm}=0.3937 \mathrm{inch}, \mathrm{l} \mathrm{g}=0.0353 \mathrm{oz}$.

${ }^{{ }^{\prime}}$ Numbers in parentheses denote (by weight) respective percentages of parent materials. Biopolyurethance coating was applied at Iowa State University, Ames, IA.

$*, * *, * * *$ Significant at $P \leq 0.05,0.01$, or 0.001 , respectively. Means within columns that share lowercase letters do not differ based on Tukey's honest significant difference test at $P \leq 0.05$.

PLA = polylactic acid; SP.A = soy polymer with adipic anhydride.

Table 7. Diameter and shoot dry weight of 'Wave ${ }^{\circledR}$ Purple Improved Prostrate' petunia grown in seven types 4.5-inch (11.43 $\mathrm{cm}$ ) top-diameter biocontainers and petroleum plastic (control) filled with substrate that comprised (by vol) $75 \%$ canadian sphagnum moss and $25 \%$ perlite, and treated with $2-\mathrm{fl} \mathrm{oz}(59.1 \mathrm{~mL})$ aliquots of deionized water containing $0,1,2.5,5,10$, or $20 \mathrm{mg} \cdot \mathrm{L}^{-1}$ paclobutrazol. Data were collected 6 weeks after transplant. Linear $(\mathrm{L})$ and quadratic regression analyses were performed within container type across paclobutrazol concentration, and mean separation were performed within paclobutrazol concentration across container type.

\begin{tabular}{|c|c|c|c|c|c|c|c|}
\hline \multirow[b]{2}{*}{ Container type ${ }^{y}$} & \multicolumn{6}{|c|}{ Paclobutrazol concn $\left(\mathrm{mg} \cdot \mathrm{L}^{-1}\right)^{\mathrm{z}}$} & \multirow[b]{2}{*}{ Significance } \\
\hline & 0 & 1 & 2.5 & 5 & 10 & 20 & \\
\hline & \multicolumn{6}{|c|}{$\operatorname{Diam}(\mathrm{cm})^{\mathrm{z}}$} & \\
\hline PLA-SP.A $(60 / 40)$ & $36.0 \mathrm{ab}$ & $41.0 \mathrm{a}$ & $35.6 \mathrm{a}$ & $30.2 \mathrm{ab}$ & $28.1 \mathrm{a}$ & $27.8 \mathrm{a}$ & $\mathrm{L}^{* * *}, \mathrm{Q}^{* * *}$ \\
\hline Biopolyurethane-coated paper & $35.2 \mathrm{ab}$ & $32.3 \mathrm{~b}$ & $32.4 \mathrm{ab}$ & $25.3 \mathrm{bc}$ & $26.5 \mathrm{a}$ & $21.9 \mathrm{bc}$ & $\mathrm{L}^{* * *}, \mathrm{Q}^{* * *}$ \\
\hline Uncoated paper & $28.9 \mathrm{bc}$ & $30.7 \mathrm{~b}$ & $29.8 \mathrm{ab}$ & $25.4 \mathrm{bc}$ & $25.0 \mathrm{a}$ & $23.2 \mathrm{ab}$ & $\mathrm{L}^{* * *}, \mathrm{Q}^{* * *}$ \\
\hline Peat & $23.4 \mathrm{c}$ & $20.6 \mathrm{c}$ & $21.9 \mathrm{c}$ & $21.6 \mathrm{c}$ & $19.7 \mathrm{~b}$ & $17.6 \mathrm{c}$ & $\mathrm{L}^{* *}, \mathrm{Q}^{*}$ \\
\hline \multirow[t]{2}{*}{ Petroleum plastic } & 36.9 a & $33.5 \mathrm{ab}$ & $34.5 \mathrm{a}$ & $29.6 \mathrm{ab}$ & $27.5 \mathrm{a}$ & $24.8 \mathrm{ab}$ & $\mathrm{L}^{* * *}, \mathrm{Q}^{* * *}$ \\
\hline & \multicolumn{6}{|c|}{ Shoot dry wt $(g)^{z}$} & \\
\hline PLA-lignin $(90 / 10)$ & $7.1 \mathrm{bcd}$ & $6.7 \mathrm{ab}$ & $6.4 \mathrm{ab}$ & $5.5 \mathrm{ab}$ & $4.6 \mathrm{ab}$ & $4.3 \mathrm{~b}$ & $\mathrm{~L}^{* * *}, \mathrm{Q}^{* * *}$ \\
\hline PLA-SP.A (60/40) & $7.9 \mathrm{ab}$ & $7.8 \mathrm{a}$ & $6.9 \mathrm{a}$ & $6.5 \mathrm{a}$ & $5.4 \mathrm{a}$ & $5.1 \mathrm{a}$ & $\mathrm{L}^{* * *}, \mathrm{Q}^{* * *}$ \\
\hline Peat & $2.6 \mathrm{f}$ & $2.5 \mathrm{~d}$ & $2.4 \mathrm{~d}$ & $2.3 \mathrm{~d}$ & $2.0 \mathrm{~d}$ & $2.0 \mathrm{~d}$ & $\mathrm{~L}^{* * *}, \mathrm{Q}^{* * *}$ \\
\hline Petroleum plastic & $7.6 \mathrm{abc}$ & $6.6 \mathrm{ab}$ & $6.3 \mathrm{ab}$ & $5.2 \mathrm{~b}$ & $4.7 \mathrm{ab}$ & $4.1 \mathrm{~b}$ & $\mathrm{~L}^{* * *}, \mathrm{Q}^{* * *}$ \\
\hline
\end{tabular}

${ }^{\mathrm{z}} \mathrm{l} \mathrm{mg} \cdot \mathrm{L}^{-1}=1 \mathrm{ppm}, \mathrm{l} \mathrm{cm}=0.3937$ inch, $1 \mathrm{~g}=0.0353 \mathrm{oz}$.

y Numbers in parentheses denote (by weight) respective percentages of parent materials. Biopolyurethance coating was applied at Iowa State University, Ames, IA

$*{ }^{* *}, * * *$ Significant at $P \leq 0.05,0.01$, or 0.001 , respectively. Means within columns that share lowercase letters do not differ based on Tukey's honest significant difference test at $P \leq 0.05$.

PLA = polylactic acid; SP.A $=$ soy polymer with adipic anhydride. 
flowered latest, and flowering was delayed by about $3 \mathrm{~d}$ compared with that of plants grown in petroleum plastic containers (Table 4). However, differences in time to flower caused by container type are likely not commercially significant for plants produced in peat containers. Similarly, differences in time to flower caused by paclobutrazol concentrations that result in appropriate growth control are likely not commercially significant. For example, flowering of angelonia and petunia treated with $1-10 \mathrm{mg} \cdot \mathrm{L}^{-1}$ paclobutrazol was delayed by up to about $3 \mathrm{~d}$ compared with untreated plants, but again this does not appear to be commercially significant. Although flowering of angelonia treated with $20 \mathrm{mg} \cdot \mathrm{L}^{-1}$ was delayed by $4.1 \mathrm{~d}$, which could be significant to commercial producers, plants were too small and not commercially acceptable (Fig. 1). Further investigation into the effects of biocontainers on flowering of other bedding-plant species may be beneficial.

Increasing paclobutrazol concentration led to suppressed height of angelonia and diameter of angelonia and petunia across biocontainer types, with growth suppression increasing with concentration (Tables 4-7). Research has demonstrated that growth inhibition of containerized ornamental plants increases with increasing concentrations of PGRs up to a species- or cultivar-specific concentration, at which suppression is saturated (Barrett, 1982; Currey et al., 2016b, 2016a; De Hertogh et al., 1976; Whipker et al., 2006). Our results reflected these findings.

Although inhibition of angelonia and petunia growth followed a similar trend across biocontainers with increasing paclobutrazol concentrations, the magnitude of growth suppression was greater for plants grown in certain types of biocontainers. For example, diameter of angelonia grown in peat containers and treated with $1-20 \mathrm{mg} \cdot \mathrm{L}^{-1}$ paclobutrazol was $36 \%$ to $56 \%$ smaller than that of plants grown in petroleum plastic containers at the same concentrations, whereas plants grown in coir containers were only $18 \%$ to $38 \%$ smaller (Table 6). Similar trends were observed among petunia (Table 7). These results support our hypothesis that biocontainers influence PGR drench efficacy differently depending on the type of container.

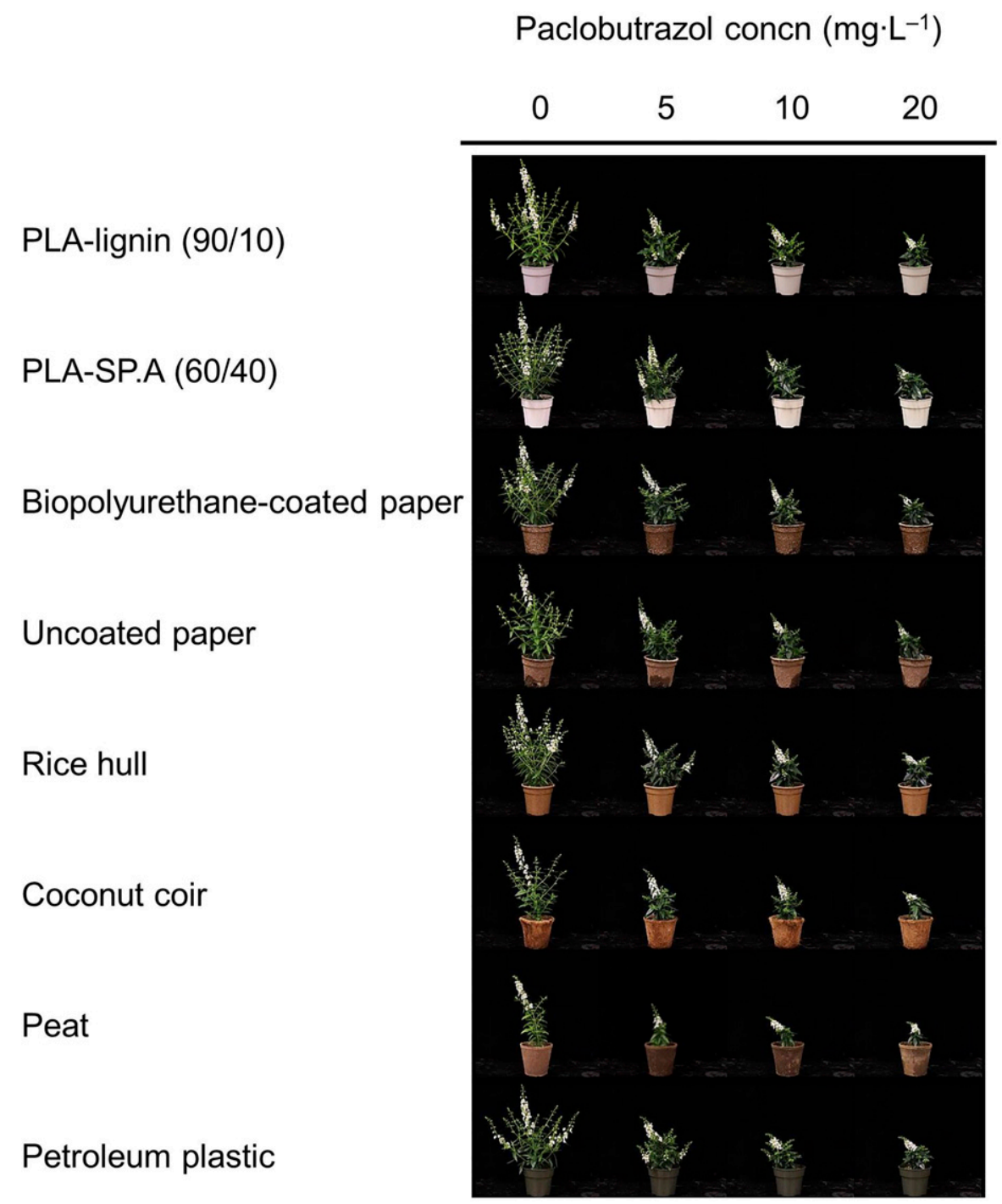

Fig. 1. 'Serena White' angelonia grown in seven types of biocontainers 4.5-inch $(11.43 \mathrm{~cm}$ ) top-diameter novel biopolymer containers made from (by weight) $90 \%$ polylactic acid [PLA (a commercial biopolymer)] and 10\% lignin powder [PLAlignin $(90 / 10)], 60 \%$ PLA, and $40 \%$ soy polymer with adipic anhydride $\{$ SP.A [PLA-SP.A $(60 / 40)]\}$, recycled paper fiber twice dip-coated in a castor oil-based biopolyurethane (biopolyurethane-coated paper), commercially available recycled paper fiber (uncoated paper), rice hull, coconut coir, peat, or a petroleum plastic (control) container filled with substrate that comprised (by vol) $75 \%$ canadian sphagnum moss and $25 \%$ perlite, and treated with $2-\mathrm{fl} \mathrm{oz}(59.1 \mathrm{~mL})$ aliquots of deionized water containing $0,1,2.5,5,10$, or $20 \mathrm{mg} \cdot \mathrm{L}^{-1}$ paclobutrazol. Photos were taken 6 weeks after planting. Plants treated with 1 or $2.5 \mathrm{mg} \cdot \mathrm{L}^{-1}$ paclobutrazol were excluded from the figure for clarity; $1 \mathrm{mg} \cdot \mathrm{L}^{-1}=1 \mathrm{ppm}$.

Despite irrigating plants nonuniformly in a manner similar to Evans and Hensley's (2004) second experiment, to ensure that available water was not a limiting factor in plant growth, differences in growth among plants treated with $0 \mathrm{mg} \cdot \mathrm{L}^{-1}$ paclobutrazol occurred. Angelonia and petunia grown in peat containers and the diameter of angelonia grown in coir containers treated with $0 \mathrm{mg} \cdot \mathrm{L}^{-1}$ were also smaller than those of plants grown in petroleum plastic containers (Tables 4, 6, and 7). Angelonia and petunia SDW for plants grown in peat and coir containers exhibited similar trends (Tables 6 and 7). We believe that reduced availability of water due to the porous, absorbent, or both properties of fiber-based containers used in this experiment may have been the cause of growth inhibition for plants grown in coir and peat containers. 
Other research has investigated the effects of porous and absorbent properties of biocontainers on growth and quality of bedding plants. In an experiment comparing growth of four flowering annual beddingplant species in peat and poultryfeather pots with those grown in petroleum plastic containers, plants produced in peat containers were smaller than those grown in petroleum plastic (Evans and Hensley, 2004). In a subsequent study, Evans et al. (2010) also reported that geranium (Pelargonium $\times$ hortorum 'Orbit Cardinal') produced in 4-inchdiameter peat, paper fiber, or coconut coir containers required more frequent irrigation and greater total volume of water compared with those in petroleum plastic containers to produce marketable plants. Our results are consistent with these findings with respect to reduced growth and increased water requirements for plants produced in peat and coconut coir containers. In our experiment, angelonia grown in coir and peat containers treated with $0 \mathrm{mg} \cdot \mathrm{L}^{-1}$ paclobutrazol required 30 and 34 irrigations, respectively, compared with those in petroleum plastic containers which required only 20 . Similarly, untreated petunia grown in coir and peat required 26 and 28 irrigations, respectively, compared with plants grown in petroleum plastic containers that required 19.

We do not believe that the release of additional mineral nutrients from SP.A-based bioplastic containers influenced paclobutrazol drench efficacy. Schrader et al. (2013) reported that containers manufactured with SP.A release mineral nutrients that are available to plants during production as container materials degrade. We hypothesized that this added "fertilizer effect" of SP.A bioplastic containers would diminish PGR drench efficacy by increasing plant growth and, therefore, increase paclobutrazol concentrations required for appropriate control. However, McCabe et al. (2016) reported that when plants that release fertilizer grown in biocontainers are provided with additional water-soluble fertilizer, the "fertilizer effect" is negated. Our results align with these findings, as plants produced in PLA-SP.A containers were provided with the same amount of fertilizer as plants in other containers and had comparable height, diameter, or SDW to plants in petroleum plastic and other nonporous containers, including those treated with $0 \mathrm{mg} \cdot \mathrm{L}^{-1}$ paclobutrazol (Tables 4, 6, and 7).

We postulate that differences in the magnitude of growth suppression of plants produced in coir and peat containers compared with other containers were a result of reduced availability of water imparted by the containers themselves, not by reducing or enhancing the activity of the PGR as some substrate components do (Barrett, 1982; Bonaminio and Larson, 1978). Plants produced in biocontainers made from permeable or porous materials may be smaller than those grown in petroleum plastic containers or biocontainers that more closely resemble conventional plastic pots. For example, untreated angelonia in peat containers were closer in size to plants in other container types treated with $5 \mathrm{mg} \cdot \mathrm{L}^{-1}$ paclobutrazol than plants in these containers were to their respective untreated controls (Fig. 1). Similar trends among petunia were observed (Fig. 2). Beddingplant producers who have limited resources or are unable to irrigate crops more frequently than once per day may want to consider avoiding porous biocontainers or they could use shuttle trays with porous biocontainers in their production scheme to reduce irrigation needs (Evans et al., 2015). For commercial producers

\section{Paclobutrazol concn $\left(\mathrm{mg} \cdot \mathrm{L}^{-1}\right)$}

0

PLA-lignin (90/10)

PLA-SP.A (60/40)

Biopolyurethane-coated paper

Uncoated paper

Rice hull

Coconut coir

Peat

Petroleum plastic

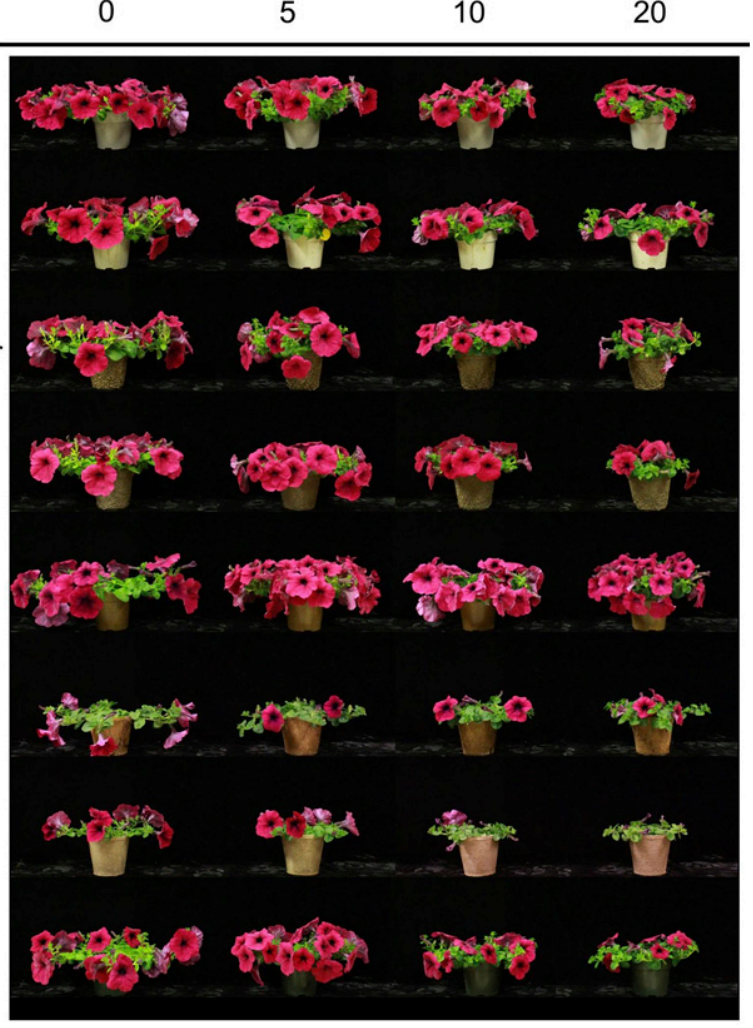

Fig. 2. 'Wave ${ }^{\circledR}$ Purple Improved Prostrate' petunia were grown in seven types of 4.5 -inch $(11.43 \mathrm{~cm})$ top-diameter biocontainers: novel biopolymer containers made from (by weight) $90 \%$ polylactic acid [PLA (a commercial biopolymer)] and $10 \%$ lignin powder [PLA-lignin $(90 / 10)$ ], $60 \%$ PLA, and $40 \%$ soy polymer with adipic anhydride $\{$ SP.A [PLA-SP.A $(60 / 40)]\}$, recycled paper fiber twice dip-coated in a castor oil-based biopolyurethane (biopolyurethane-coated paper), commercially available recycled paper fiber (uncoated paper), rice hull, coconut coir, peat, or a petroleum plastic (control) container filled with substrate that comprised (by vol) $75 \%$ canadian sphagnum moss and $25 \%$ perlite, and treated with 2 -fl oz $(59.1 \mathrm{~mL})$ aliquots of deionized water containing $0,1,2.5,5,10$, or $20 \mathrm{mg} \cdot \mathrm{L}^{-1}$ paclobutrazol. Photos were taken 6 weeks after planting. Plants treated with 1 or $2.5 \mathrm{mg} \cdot \mathrm{L}^{-1}$ paclobutrazol were excluded from the figure for clarity; $1 \mathrm{mg} \cdot \mathrm{L}^{-1}=1 \mathrm{ppm}$. 
who use coconut coir and peat containers, we recommend a decrease in paclobutrazol drench concentrations compared with concentrations commonly used with petroleum plastic containers to prevent the potential for excessive growth inhibition.

\section{Literature cited}

Alem, P., P.A. Thomas, and M.W. van Iersel. 2016. Controlled water deficit as an alternative to plant growth retardants for regulation of poinsettia stem elongation. HortScience 50:565-569.

Andersson, N.E. 2011. The influence of water stress and air velocity on growth of Impatiens walleriana and Petunia $\times$ bybrid. Scientia Hort. 128:146-151.

Barrett, J.E. 1982. Chrysanthemum height control by ancymidol, PP333, and EL-500 dependent on medium composition. HortScience 17:896-897.

Blanchard, M.G. and E.S. Runkle. 2011. The influence of day and night temperature fluctuations on growth and flowering of annual bedding plants and greenhouse heating cost predictions. HortScience 46:599-603.

Boldt, J.L. 2008. Whole plant response of chrysanthemum to paclobutrazol, chlormequat chloride, and (s)-abscisic acid as a function of exposure time using a splitroot system. Univ. Florida, Gainesville, MS thesis.

Bonaminio, V.P. and R.A. Larson. 1978. Influence of potting media, temperature, and concentration of ancymidol on growth of Chrysanthemum morifolium Ramat. J. Amer. Soc. Hort. Sci. 103:752756.

Conneway, R., S. Verlinden, A.K. Koeser, M.R. Evans, R. Schnelle, V. Anderson, and J.R. Stewart. 2015. Use of alternative containers for long- and short-term greenhouse crop production. HortTechnology 25:26-34.

Currey, C.J., D.M. Camberato, A.P. Torres, and R.G. Lopez. 2010. Plant growth retardant drench efficacy is not affected by substrate containing parboiled rice hulls. HortTechnology 20:863-866.

Currey, C.J., N.J. Flax, and K.J. Walters. 2016a. Foliar sprays of flurprimidol, paclobutrazol, and uniconazole suppress height of seed-propagated new Guinea impatiens. HortTechnology 26:20-25.

Currey, C.J., K.G. McCabe, J.A. Schrader, W.R. Graves, J.J. Behrens, and D. Grewell. 2015. Biocontainers 2.0. GrowerTalks 79(5):74-78.

Currey, C., J. Schrader, K. McCabe, W. Graves, D. Grewell, G. Srinivasan, and S. Madbouly. 2014. Bioplastics for greenhouses. Soy what? GrowerTalks 77(8):70-74.

Currey, C.J., K.J. Walters, and K.G. McCabe. 2016b. Quantifying growth control of lantana cultivars varying in vigor with ancymidol, flurprimidol, paclobutrazol, and uniconazole substrate drenches. HortTechnology 26:320-326.

De Hertogh, A.A., N. Blakely, and W. Szlachetka. 1976. The influence of ancymidol, chlormequat and daminozide on the growth and development of forced Dablia variabilis Willd. Scientia Hort. 4:123-130.

Erwin, J.E., R.D. Henis, and M.G. Karlsson. 1989. Thermomorphogenesis in Lilium longiflorum. Amer. J. Bot. 76:47-52.

Evans, M.R. and D.L. Hensley. 2004. Plant growth in plastic, peat, and processed poultry feather fiber growing containers. HortScience 39:1012-1014.

Evans, M.R., A.K. Koeser, G. Bi, S. Nambuthiri, R. Geneve, S.T. Lovell, and J.R. Stewart. 2015. Impact of biocontainers with and without shuttle trays on water use in the production of a containerized ornamental greenhouse crop. HortTechnology 25:35-41.

Evans, M.R., M. Taylor, and J. Kuehny. 2010. Physical properties of biocontainers for greenhouse crops production. HortTechnology 20:549-555.

Faust, J.E., V. Holcombe, N.C. Rajapakse, and D.R. Layne. 2005. The effect of daily light integral on bedding plant growth and flowering. HortScience 40:645-649.
Gent, M.P.N. and R.J. McAvoy. 2000. Plant growth retardants in ornamental horticulture, p. 89-146. In: A.S. Basara (ed.). Plant growth regulators in agriculture and horticulture: Their role and commercial uses. Food Products Press, Binghamton, NY.

Grewell, D., G. Srinivasan, J. Schrader, W. Graves, and M. Kessler. 2014. Sustainable materials for horticultural application. Plast. Eng. 70:44-52.

Hawkins, S.M., J.M. Ruter, and C.D. Robacker. 2015. Spray and drench treatments of paclobutrazol influence growth of Dissotis and Tibouchina. HortScience 50:1514-1517.

Klock-Moore, K.A. and T.K. Broschat. 2001. Irrigation systems and fertilizer affect petunia growth. HortTechnology $11: 416-418$

McCabe, K.G., J.A. Schrader, C.J. Currey, D. Grewell, and W.R. Graves. 2016. Soy composite biocontainers allow for reduced fertilizer inputs during containercrop production. HortScience 51:927934.

Owen, W.G., B.E. Jackson, B.E. Whipker, and W.C. Fonteno. 2016. Paclobutrazol drench activity not affected in sphagnum peat-based substrates amended with pine wood chip aggregates. Hort Technology 26:156-163.

Schrader, J.A., G. Srinivasan, D. Grewell, K.G. McCabe, and W.R. Graves. 2013. Fertilizer effects of soy-plastic containers during crop production and transplant establishment. HortScience 48:724-773.

U.S. Department of Agriculture. 2015. Census of horticultural specialties 2014. 25 Mar. 2016. <http://www.agcensus. usda.gov/Publications/2012/Online_ Resources/Census_of_Horticulture_ Specialties/HORTIC.pdf $>$.

Whipker, B.E., I. McCall, and B.A. Krug. 2006. Flurprimidol substrate drenches and foliar sprays control growth of 'Blue Champion' exacum. HortTechnology 16: 354-356. 